FACTA UNIVERSITATIS

Series: Law and Politics Vol. 15, No 2, 2017, pp. 115 - 125

DOI: $10.22190 /$ FULP1702115M

Original Scientific Article

\title{
VIRTUAL REALITY AND ETHICAL NEUTRALITY OF THE VIRTUAL SUBJECTS OF LAW ${ }^{1}$
}

\author{
UDC 340.1:17
}

\section{Dragan Mitrović}

University of Belgrade, Faculty of Law, Republic of Serbia

\begin{abstract}
The existence of legal reality implies the existence of the subjects of law as the creations of that reality. The law cannot even exist without its subjects. They are conditio sine qua non for the law. First, natural persons had become the subjects of law-although not all of them and not at the same time, and thereafter their creations - legal (moral) persons, also became the subjects of law. In both cases, it is about traditional virtual legal creations. However, as the information and technological developments could not have bypassed contemporary law, more and more frequently and intensively it is being thought about the third type of the subjects of law - virtual characters as the new subjects of law (law avatars). Today, this is not done out of curiosity, but for very practical reasons -i.e. for promoting business communication that is rapidly migrating to the area of computer virtual reality. Such a change requires reconsideration of traditional beliefs and theories about what a subject of law is. It also requires determining the possible legal nature of virtual characters, irrespective of whether it is about virtual natural or legal persons. When it comes to the explanation of their essence, it seems that at this moment the fiction theory is more acceptable than the reality theory, which might prevail sometime, as it had happened with the subjectivity of the legal person at some point in time in the 17th century.
\end{abstract}

Key words: subject of law. - natural person - legal person - virtual character - ethics.

\section{THE ORIGIN AND MEANING OF THE TERM "VIRTUAL REALITY"}

The term virtual reality $(V R)$ in the sense used today was first coined and used in 1984 by William Gibson, the writer of the novel "Neuromancer". However, pioneer experiments that allowed creating the technology for specific development of virtual reality were performed in the USA somewhat earlier, in the mid-sixties of the 20th century. Since that time, the technology required for creating and testing the capabilities of that newly-

Received June $5^{\text {th }}, 2016 /$ Accepted June $19^{\text {th }}, 2017$

Corresponding author: Dragan Mitrović

University of Belgrade, Faculty of Law, Kralja Aleksandra Blvd. 67, 11000 Belgrade Republic of Serbia

E-mail: draganm@ius.bg.ac.rs

${ }^{1}$ This article has been adapted, polished and previously published in "The Journal on Legal and Economic Issues of Central Europe“, London, Vol. 3, 2012, No. 1, pp. 2-8, the publication of which ceased in 2016. 
discovered virtual reality has been developed in the laboratories of several leading American universities. In the early seventies, it was already understood that an entirely new "imagination world" could be created with the use of computers that was additionally capable of self-development in the memories of the most powerful computers.

However, this new and extremely challenging opportunity was not created by artists, but by mathematicians, who further developed and advanced the theories of virtual reality, pursuant to their scientific intentions. Soon afterwards, due to the increased reliability of computer simulation, complete new systems were developed. They were supported by suitable "intelligent" software, actually suitable "expert systems", whose task was to develop a special kind of "computer intelligence" based on the "common sense algorithm". Thereby, the expert systems in the area of computing became the basis for establishing the relationship between the computer virtual world and the world of true, "objectified" or physical reality, and not only for developing the virtual reality (Popper, 1991: 236-237; Mitrović, 2000: 62-68, 115-116). Exactly those kinds of relationships allowed scientific development to move in new direction and take new course due to the use of computer simulation. That development couldn't bypass the law. On the other hand, computer simulation $(C S)$, the use of which proves that there is a virtual reality, represents a numerical technique for creating synthetic symbolic or realistic images and characters uniting informatics, telecommunications and the audiovisual. Moreover, the development of numerical techniques, relying on new numerical technologies, allows the creation of an entire parallel universe - synthetic and ever more probable, wherein one does not have to ask any more what can be done - since in that universe everything can be done - but instead, what we would have to do. Such an opportunity casts a new light on the task of computer simulation - its task is no more to provide the data and estimates, but to provide experience! And this completely changes the ingrained idea of what reality is.

A somewhat unusual answer to the question what reality is can be found in Buddhism, and it is given by Ashvagosha, who says that "All phenomena in the world are nothing but the illusory manifestation of the mind and have no reality on their own" (Ashvaghosha, 1900: 79; Capra, 1989: 330). According to another well-known school of Yogacara, the reason for that is the following: "Out of mind spring innumerable things, conditioned by discrimination. These things people accept as an external world. What appears to be external does not exist in reality; it is indeed mind that is seen as multiplicity; the body, property, and above-all these, I say, are nothing but mind" (Suzuki, 1952: 242). All forms we perceive are "mind only"; "projections", or "shadows of the mind": Similar thoughts and the answer to the question what reality is can also be encountered in modern science, since it is no longer capable of answering the questions that can be asked using traditional apparatus. And the answer to the question what virtual reality is depends on the answer to those questions.

\section{VIRTUAL REALITY AND MEANING AS BEING}

So, what is reality, or is the meaning the same as being, as emphasized by David Bohm, Rupert Sheldrake and other writers holding similar belief and orientation, and is the virtual world also real as the true world, if meaning is the same as being? (Bohm, 2002: 11).

The aforementioned writers give an affirmative answer to that question. According to them, the meaning or meaningfulness represents the basic qualities of reality. Reality is indirectly held within meanings, since everything that is known about the reality has to be 
somehow related to the meaning it has to us. And this says that meaning is always a whole! The essence is that there is no separation, although the meaning may not always be fixed. For example, when we interpret a theory, we arrive at its meaning. And as a rule, the theories are always ambiguous, which in the end shows that the composition of meaning is such that the highest, utmost meaning can never be reached. Even so, the meaning is inexhaustible, despite its significant limitation. It has no boundaries, since it is endless, depending in each individual instance on the context where it is used. As the context changes, so does the meaning, along with the being. It seems as though that idea presents a reliable base for performing computer simulation, when the same or different meanings are examined in the virtual computer world to establish potential virtual or real being of the phenomena or systems. That meaning can be a virtual social character (person), but also a subject of law (law avatar).

The aforementioned writer David Bohm says the following about the relationship of meaning and being: "meaning becomes being (and vice-versa). Through this process, meaning and being come to reflect each other. But ultimately, meaning is being. As with form and content, we make the distinction between meaning and being in order to express our thought. But this distinction does not imply a real difference - it is the way by which we understand one ultimately undivided whole. At the stage in which meaning and being reflect each other, they may be treated as separate. But in the deeper stage, meaning and being have to be seen as essentially one" (Bohm, 2002: 87-89).

Bohm explains the aforementioned assertion by connecting the meaning and sense to the notion of information. According to Bohm, the operative notion in relation with information is the notion of form. To constitute a form, information has to have some meaning. Literally "to inform" means "to put form into", "to shape" some meaning. Therefore, the change of meaning leads to the change of form. The change of the form of information leads to the change of its content, and thereby - through a feedback - to the change of its meaning! In other words, each form that has meaning may create potential or actual information being equally significant for the real and virtual world.

\section{VIRTUAL REALITY AS A “NATURAL” ENVIRONMENT FOR PERFORMING COMPUTER SIMULATION}

Bohm's connecting the meaning, information and being opens the possibility for the successful simulation of diverse models, ranging from natural to social and cultural ones, since every meaning can be transformed into information that can be given an appropriate form. For that reason, computer simulation of the models in virtual reality, to the same extent represents the examination of meaning with form and through form. Such meaning in a virtual world is the same as being. However, while meaning and being in the virtual world are always directly one and the same, in the real world they are so only indirectly. Fortunately, this has not the slightest effect either on the possibility of the successful use of computer simulation, or on the reliability and verifiability of the obtained results, which can be pretty much valuable in the true reality. It appears that the ability of rational mind to differentiate between true and virtual reality is the very essential measure for differentiating between these two realities. Because of that, the explanation of the notion of reality, "in one area of research, wherein it is more and more clearly perceived that the patterns of matter and the patterns of mind reflect each other, promises that fascinating areas of knowledge will be opened" (Capra, 1989: 381). 
The aforementioned connection is confirmed by new virtual reality computer techniques. These are already immense at the present moment, particularly when under specified conditions the simulation of non-deterministic models of social or legal phenomena and systems is performed. The aforementioned techniques and their capabilities show that the power of the virtual is limited only by our imagination.

Computer simulation and new virtual reality techniques have yet to find their place in the law science and the law. Even though the law has always existed as virtual phenomenon (usually as a personal or collective conventional conception), not until now this aspect of law could have been used for creating a synthetic realistic, virtual world of law (legal notions, phenomena and systems), wherein also we can submerge, move within, act and evolve. The only limits are our imagination, intentions and prejudices.

With regard to the possibilities offered by computer simulation and virtual reality, while connecting the law with the art of imagination, other cognitive and practical possibilities are even more captivating for the application in law - for example, if the course of some specific judicial investigation or legal proceeding would be numerically recorded from the first to the last moment. In this way, it would be possible to reconstruct the entire course of the proceedings to truly recover it, along with the possibility to participate in it or change it according to the desires and needs. This would provide extraordinary opportunities for the training of lawyers, who also could elaborate potential courses and outcomes of legal or some other actions, in three-dimensional virtual space and specified time, in their virtual law classroom. Such virtual revival has yet another precious feature, since the entire course of the proceeding may be slowed down or accelerated, as desired, to completely change the testimonies and arguments of the parties, and thereby the very course of the proceeding at any time, or to examine the course of the proceeding by setting the conditions otherwise not present in numerically recorded actual judicial investigation or legal procedure (Flusser, 1990: 266-277, 287). The same results could also be achieved in some other legal action (legislative, administrative, arbitration, etc.).

This could also be applied on testing the results of other legal disciplines. For example, in criminology, the character traits of a person could be reliably reconstructed based on a person's handwriting, or, vice versa, a person's handwriting based on his/her character traits (for example, on the foundations of Lombroso's graphological findings on the connections between classified handwriting types and the characteristics of the personality types). An expert can also do this directly, but not in such a comprehensive manner, and not in such a short time as when using computer simulation. The same method can be used in criminology and penology, for example, when examining the effect of punishment on the behaviour of convicts under specified conditions. This could be done even if there is no culprit, guilt and punishment, i.e. when virtually examining an imagined situation. In addition, in civil law, a buyer and a seller could sign a sales contract based on virtual flat viewing or based on examining the quality of a commodity, in a manner that none of them is present in the flat or at the location of the commodity. Capabilities of the virtual could be used for examining the work of any other governmental body or some international institution. In this way, lawyers could attain reliable law knowledge and additional law skills by moving only in that virtual reality.

The advantages of the virtual could be used in other branches of science as well. Such extraordinary opportunities make the virtual reality and computer simulation the most upto-date and ever more important means of research, decision-making and management. Of course, this does not mean that such virtual reality has replaced or completely pushed out 
the true reality, but that it has just become a new powerful means of modern technology that will help in familiarizing and understanding the law, as an important part of reality, as well as possible. Still, these will not be the only such opportunities for using the world of the virtual in the law, since these are unknown and almost endless. There is no reason not to use such opportunities to examine some more interesting things: whether a virtual character can also be a subject of law, and not only whether virtual social characters (virtual personalities) can exist, as they were the first to appear in virtual reality.

\section{LEGAL REALITY AND THE THREE WORLDS OF LAW}

And now, a brief summary of the same subject from the perspective of the law. First of all, what the legal reality is and what it consists of, and then, what a legal personality is, and what a subject of law. Obviously, legal reality appeared first, and after that its subjects, or entities. As the oldest virtual creations, subjects represent conditio sine qua non of the law.

It is more than obvious that legal reality exists. For example, a legal marriage exists until it is dissolved, even if it has never been consumed, whereas the true matrimony between persons who have never been legally married usually is not considered a marriage. In this way, the law not only reflects, but goes beyond the true world, creating an entire own legal metaworld that overhangs the world of physical reality.

That world of law spreads in three planes, i.e. in three realities: physical, true and virtual, and for that reason there are also three main worlds of law: "true or natural world" (world of physical reality), "legal world" (world of legal reality) and "metalegal world" (world of legal metareality). All the three worlds spread like circles crossing each other. The central place of the law is located in the legal world (metaworld), as an intermediary between the physical world and metalegal world of ideas.

The first, "true world" (world of physical reality) represents a physical world, the world of physical objects and forces in the broadest sense of the word. That is the natural world which "has no beginning and no end", "as a whole, of unalterable size", "enclosed by "nothingness' as by a boundary" (Nietzsche, 1976: 432). In that dynamic, processed physical world, at a certain time of its development, man appears as a "being endowed with spirit", and also the law appears as an integral part of that world (since "in infinite time, at some time or another, every possible combination could be - actually must be! - realized"). The law first emerges from that world in the form of material legal sources, and then re-emerges into it in the form of materialized meaning as realized, objectified law. In that physical world of causes and consequences, the law exists as something that "is".

The second, "legal world" (world of legal reality) is a metaworld of thought processes and subjective experiences, which in normative form overhang the physical reality, producing the consequences that would not exist if there were no commands. Therefore, this is the true world wherein a "being endowed with spirit" resides, capable to learn, create, examine and apply the law. From that world of thought processes and subjective legal experiences, the law appropriately acts upon the true reality. (It has already been mentioned that the marriage as actual co-existence of man and woman does not produce the same consequences as a nonconsumed legal marriage.) Because of that, the legal world overhangs and goes beyond physical reality by its special legal reality from which it acts upon physical reality. In that legal world, the law at the same time exists as something that "is", and as something that "needs to be". It "is", since the meaning is one type of existence. However, it is also something that 
"needs to be", since the question is about a determined meaning issued in the form of an appropriate command that is to be materialized.

The third, "metalegal world" (world of legal metareality) is a meta-metaworld of legal statements, theories, problems and (critical) assertions. It is a pure product of human mind and human activity, which overhangs the physical and legal world. However, that metalegal world, in a broader sense, also includes all the products of human mind (legal notions, institutions, procedures or legal works). Even so, this has not the slightest effect on its reality, since it is real as are all human products in general - from language codes to such social institutions as "university or police" (Popper, 1991: 93). It has its history (the history of our ideas) and its values (created by human mind). But, although purely virtual, it is not self-sufficient, since nothing that exists is deprived of the meaning and purpose. In addition, its content, if only indirectly and only partially, is related to the law spreading in the two previous worlds. Therefore, that is the world of legal metareality, the world wherein the law is always something that "needs to be".

Metalegal world is a pure product of human mind. We are the ones who create the objects of that world. And the fact that these objects have their inherent and autonomous laws, which create unintentional and unpredictable consequences, it is a mere example (although extremely interesting) of a more general rule that all our acts have such consequences. For that reason, metalegal world should be viewed as a product of human activity with consequences to us as great - or greater - than in the physical environment. There is a kind of a feedback in every human activity: "in acting we always act, indirectly, upon ourselves also" (Popper, 1991: 93-94). This feedback to the same extent also applies to the legal world, which is constantly emerging from the physical world and into which it is constantly re-emerging.

Physical world is a world of the material sources of law and materialized law. Legal world is a world of formal sources and systematized law. Metalegal world is a world of legal notions (statements, theories, problems and critical claims). Since the first world by itself is not legally active, and the third one in not legally effective, there is a legal world as an intermediary between the first and the third world, between pure matter and pure ideas. That legal world provides necessary connectivity, meaningfulness and expediency for all the three holistically created worlds of law.

Among the aforementioned worlds of law, there is a constant intertwining. It is performed in cycles representing the law as an imperfect phenomenon that cannot be fully understood, and that is driven by permanent instability. In the law, appropriate norms are continuously created and cancelled by legal acts; appropriate relations appear, change and cease; the position of the subjects of law performing various material actions and acting in a certain way according to legal norms is changed, etc. And that constant motion takes place in a certain order, meaning that the law itself includes the rules according to which that motion is performed. This allows us to conclude that there are two more sub-worlds within the virtual world of law: legal world of rules (the world of rules themselves) and the legal world of metarules (the world of procedural rules on rules). The first one determines the content of legal communications, whereas the second one determines the order of the correct functioning of the rules of law and human behaviour according to these rules.

Obviously, the virtual legal reality not only exists, but it effectively influences the world of physical reality. If such legal reality has existed since the time of the appearance of the law, it follows that the only novelty is the appearance of new, computer legal virtual reality. It already exists, which is indicated by its virtual characters that are allowed to possess the characteristics of the subjects of law. 


\section{Legal Personality AND SubJeCt of LAW AS ViRTual CREATions}

The following important question is: what is a legal personality, and what the subject of law? Are these not the virtual creations of human spirit as well? First, biologically created human being had existed, and only thereafter personality appeared, i.e. a character, individual, person (from Latin word persona in the sense of ,personality", as "person", or "character", as a "mask"). It represents an upgrade, i.e. a social concept, which in the law transforms into legal personality, natural or legal person, who is acknowledged to have the property of the subject of law. Due to that, personality and subject are the same concepts in the law. Only the social concept of personality is broader than the legal concept of subject, which is a special type of social personality (Mitrović, 2010: 437-147).

The law cannot exist without persons, since it was created because of them. Nowadays, in civilized countries all people are the subjects of law. Yet, there were the orders wherein all people were no subjects, but some of them were the objects of the law. But, even if a man is individually considered as the subject of law, it can be noticed that some subjects of law have developed conscience and will, while others have no such conscience and will, and therefore can neither understand legal norms nor behave accordingly. Nevertheless, even such persons are considered to be subjects of law, since the law can do something for their benefit or charge them with something, irrespective of their conscience and will. In addition, since the Roman law until today, there have been organizations (institutions, associations, foundations, etc.) which are considered to be the subjects of law. Although not being natural persons, they are composed of natural persons, showing that man by himself is not the only subject of law. Finally, in one hypothetical and quite limited sense, the idea emerges again that, under certain conditions and to a limited extent, animals may also be the subjects of law, i.e. the holders of the passive legal capacity (Paunović, 2005: 131; Visković, 2006: 134). Obviously, the objects of law cannot be subjects of law, but subjects of law may become the objects of law (Melvinger, 1965: 392).

Subject of law in a narrower meaning represents only that individual which is subjected to the positive law of the state, but provided that it has three important features: capacity of owning (property), capacity or power of creating legal acts (formation of law) and capacity to be responsible for its illegal actions (legal liability). All the three properties together make a unique concept of the subject of law as an owner, creator of law and legally responsible person (Gams, 1988: 99 and further; Stanković, 1996: 51 and futher). The subject of law is, therefore, the holder of passive and active legal capacity, i.e. specific powers and liabilities. The both capacities are not its natural, but virtual legal features, acknowledged to people and their creations by legal order (Vukadinović, 2007: 148-149).

By passive legal capacity, the subject is connected with the powers and responsibilities determined by the law (for example, of spouse, heir, owner, creditor, debtor, etc.). That type of capacity is acquired by the birth of a natural person or by establishing and registering a legal person. And vice versa, it is lost by physical death or by closing or removing a legal person from register.

The subject of law, which is always a holder of passive legal capacity, is to be differentiated from a person that, as a holder of active legal capacity (for example, business capacity) can consciously and wilfully act according to legal norms. Such an actively (and passively) capable person is called legal agent. Acting in accordance with legal norms, he/she can operate for his/her own or someone else's benefit. In the first case, the owner is concerned, whereas in the second case, it is the representative. In case of the representative, 
there needs to be a legal representation as some kind of "replacement" with other subjects of law. For that reason, it is said that a representative is an independent and a special type of legal agent, who performs certain activities in the interest of other natural and legal persons. $\mathrm{He} / \mathrm{she}$ always acts on behalf of the represented person (representee), and consequently that person (and not legal agent as a representative) is the subject of legal activity (Zivanović, 1959: 285). For example, in the law it is considered that a person incapable to work has signed a sales contract through a representative, i.e. that person, and not one's representative, has become the subject of the property right over the purchased thing (Stojanović, Antić, 2004: 28 and futher). The relationship between the representative of a person capable to work and the represented person is similar to the relationship between the representative and the person incapable to work.

The case is somewhat more complex when determining the nature of a legal (moral) person. It also represents a virtual social creation to which the property of the subject of law is acknowledged, since it is an "adequately organized and formed" whole, which is clearly distinguished from other similar human creations. Although a legal person has no own separate conscience and will, it is nevertheless acknowledged as the subject of law, as well as a natural person that has that conscience and will. This is done because the legal person also represents a "centre of interests and activities of people", i.e. has the powers and liabilities in accordance with its character and goal for which it has been established. It is only that those powers and liabilities cannot be related to the man's capacity to be a parent, spouse or to have certain civil rights. Hence, the principle of the freedom applies to natural persons, whereas the principle of restricting the freedom applies to legal persons. Natural persons are permitted to do or not do something, as long as their behaviour is not expressly forbidden by legal norms. That is in line with the comprehension according to which everything that is not legally forbidden is free, i.e. legally allowed. Legal persons may freely do or not do something only if that is expressly allowed by legal norms, where this is in accordance with the comprehension that only what is legally permitted is free. The aforementioned difference between natural and legal persons with regard to their active and passive capacity is justified by the nature of legal persons and their specialized activities, whereby it is indicated that there is some preliminary notion about their legal nature.

Today, in the law science, there are at least three main theories explaining the nature of legal person. According to the first and the oldest theory of fiction, legal person is considered to be a fictional, artificial subject of law. According to the second theory - theory of negation, the subjectivity of a legal person as such is contested, i.e. it is considered to be a mere set of natural persons, which are the only holders of powers and liabilities. Finally, according to the third theory - theory of reality, subjectivity is acknowledged to a legal person that is considered as one centre of activity and interest. Besides the aforementioned, there are other theories explaining the essence of the legal person, for example, concession theory, organism theory, group personality theory, Ihering's "bracket theory", theory of ownership, Kelsen's theory, etc (Pound, 2000: 493-529).

Only owing to the theory of reality, a legal person can appear as a special social and legal creation having all the powers and liabilities as the natural person, or even to a greater extent than the natural person. Its essence is that the legal person is considered to be a social organization composed of as many people as possible, performing certain powers and duties on behalf of that organization. This means that the legal consequences of their actions are not attributed directly to them, but to the whole organization. Legal person is, therefore, the subject of law without a capacity to independently and directly perform its powers and 
liabilities. Instead by the legal person, this is performed by its bodies as representatives. However, the legal person as a whole also has powers and liabilities towards the members of which it is composed. The same situation exists in the case of virtual characters as new subjects of law. These also represent "centre of interest and activities of people" and "do not have the capacity to independently and directly perform their powers and liabilities", the same as the legal persons.

\section{VirTUAL COMPUTER CHARACTER AS A SUBJECT OF LAW}

The law exists not only as a real and ideal, but also as a virtual computer phenomenon uniting in itself in an unusual way the real and the ideal. This took place when the real and the ideal in the law intertwined for the first time in the virtual computer world owing to the rapid development of information technologies which imperceptibly but quickly changed the world of our notions to the same extent as our physical environment. In this way, besides the real subjects of law, natural and legal persons existing in the true reality, new virtual entities appeared, i.e. virtual characters or avatars, as also being called. They exist only in the computer virtual reality, while they do not exist in the true reality. These are completely new and autonomous subjects of law. They are new, since they have never existed before, and autonomous, since they exist only in computer virtual reality, wherein and wherefrom they can legally act.

Since virtual characters (avatars) can produce legal consequences in both realities, i.e. can act only in virtual reality or from virtual reality upon real physical and moral subjects of rights in true reality, an important question of their legal nature is posed.

The nature of virtual characters can be explained in various ways - for example, by the theory of representation, especially when it is about virtual natural persons. Its main drawback is the difficulty of explaining how a real subject of law can represent itself in a virtual computer world (for example, how a true, real person can be a guardian to its avatar or, maybe vice versa, an avatar to a real person). The answer that it is about a simultaneous double legal subjectivity of the same real subject does not appear to be either correct or acceptable, since the virtual and real subjectivities of one person are not identical. This is not the result of attributing legal actions to the same entity in the virtual and the real world. Thereby it seems that the essence of the problem of determining virtual characters is touched upon once more.

It appears that the closest to the essence of virtual characters is the fact that they can be talked about as if they explain the essence of a legal person, which in relation to a natural person is actually an illusion, but the illusion that produces extremely significant legal and social consequences. Having in mind that in the legal science there are at least three main theories explaining the essence of a legal person, according to the first, the oldest theory of fiction, virtual character still would be the subject of law, only artificial and therefore illusory. According to the second theory - theory of negation, a virtual character could not be the subject of law. This is reserved exclusively for the natural and legal persons being the only holders of powers and liabilities. Finally, according to the third theory - theory of reality, complete subjectivity could be acknowledged to a virtual character as one more centre of activity and interest, as though it is about a natural or legal person, which in some laws is already being done today.

By comparing a legal person with virtual characters, it can be noticed that virtual characters, as well as legal (moral) persons, have the capacity of ownership (property), 
capacity or power of creating legal documents (formation of law) and capacity to be responsible for their illegal acts (legal liability), as well as their identity, therefore, all that together makes a unique concept of the subject of law as an owner, creator of law and a legally responsible person, only in virtual reality. As has already been said, they only "do not possess the capacity to independently and directly perform their powers and liabilities", the same as legal persons.

It seems that for the explanation of their essence at this time the theory of fiction is more acceptable than the theory of reality, which could prevail sometime, as formerly happened with the subjectivity of a legal person.

$$
* * *
$$

Law cannot exist without subjects. They have always existed as conditio sine qua non of the law. Firstly, natural persons became subjects of law, and thereafter also their creations - legal (moral) persons.

Information and technological developments could not have bypassed contemporary law. As a result, more often and considerably more is being thought about a new, third type of the subjects of law - virtual characters (avatars). This is being done for the purpose of advancing and organising business communication, which is increasingly being translated from the traditional true world into the new virtual computer world.

This change requires the re-examination of traditional beliefs and theories concerned with what a subject of law is at all. It also requires at this moment to at least make an attempt to determine the legal nature of virtual characters. When it has to do with the explanation of their essence, it seems that at this moment the fiction theory is more acceptable than the reality theory, which may sometime prevail, as it had happened with the subjectivity of the legal person at some point in time in the 17 th century.

In addition to purely practical reasons, the appearance of virtual characters displays in a completely different light some of the incessant questions to which a valid answer has not yet been given, nor, it seems, will ever be: What is reality? What is the world at all? What is man (especially a telematic virtual man)? What is the place of man in reality and in the world? For how long can the world and man, as its constituent part, go on developing? Does virtual reality free or capture human will? An acceptable answer to these numerous questions, which are primarily ethical and biojuristical, has not yet been found. Apparently, the essence is not in the conclusiveness of such answers, but rather in their usefulness. Behind every mask of the subject of law there is a real human face.

\section{REFERENCES}

Antić, O. (2007), Law of contracts and torts, Belgrade.

Ashvaghosha (1900), The Awakening of Faith, Chicago.

Bohm, D. (2004), On Creativity, London \& New York.

Bohm, D. (2004), On Dialogue, London \& New York.

Bohm, D. (2002), Wholeness and the Implicate Order, London \& New York.

Capra, F. (1989), The Tao of Physics. An Exploration of Parallels Between Modern Physics and Eastern Mysticism, Belgrade.

Flusser, V. (1990), "A Spoon of Creativity from the Soup of Chaos", Treći program, Belgrade, winter 1990, Vol. I, No. 84, pp. 266-287.

Gams, A. (1988), Introduction to Civil Law, Belgrade. 
Melvinger, J. (1965), Introduction to Law, Novi Sad.

Merleau-Ponty, M. (2004), TheWorld of Perception, London \& New York.

Mitrović, D. M. (2016), Introducton to Law, Belgrade.

Mitrović, D. M. (2015), Autonomous Law, Belgrade.

Mitrović, D. M. (2010), Theory of the State and Law, Belgrade.

Mitrović, D. M. (2002), The Path of Law. Holistic paradigm of the world and law in the light of chaos theory and legal theory, Belgrade.

Nietzsche, F. (1976) Aus dem Nachlass der achtziger Jahre, Belgrade.

Paunović, M. (2005), The Rights of Animals, Belgrade.

Popper, K. (2002), Conjectures and Refutations, London and New York.

Popper K. (1991), Unended Quest. An Intellectual Authobiography, Belgrade.

Pound, R. (2000), Jurisprudence, Vol. II, Belgrade -Podgorica.

Stanković, O. (1996), Introduction to Civil Law, Belgrade.

Stojanović, D., Antić, O. (2004), Introduction to Civil Law, Belgrade.

Suzuki, D. T. (1952), Studies in the Lankavatara Sutra, London.

Visković, N. (2006), Theory of the State and Law, Zagreb.

Vukadinović, G. (2007), Theory of the State and Law II, Novi Sad.

Zivanović, T. (1959), The System of Synthetic Philosophy of Law, Vol. III, Belgrade.

\section{VIRTUELNA STVARNOST I ETIČKA NEUTRALNOST VIRTUELNIH SUBJEKATA PRAVA}

Pravo ne može da postoji bez subjekata. Oni postoje oduvek, kao conditio sine qua non prava. Prvo su fizička lica postali subjekti prava, a zatim i njihove tvorevine - pravna (moralna) lica.

Informatičko-tehnološki razvoj nije mogao da mimoiđe savremeno pravo. Zbog toga se sve češće $i$ sve više razmišlja o novoj, trećoj vrsti subjekata prava - virtuelnim likovima (avatarima). To se čini zbog unapređivanja i uređivanja poslovnog saobraćaja, koji iz tradicionalnog aktuelnog sveta u sve većoj meri prelazi u novi virtuelni računarski svet.

Takva promena zahteva preispitivanje tradicionalnih shvatanja i teorija o tome šta je subjekt prava uopšte. Ona takođe zahteva da se u ovom trenutku barem pokuša sa odredđivanjem pravne prirode virtuelnih likova. Izgleda da je za objašnjenje njihove suštine u ovom trenutku prihvatljivija teorija fikcije nego teorija realnosti, koja će možda jednom prevagnuti, kako se svojevremeno u XVII veku dogodilo sa subjektivitetom pravnog lica.

Pored čisto praktičnih razloga, pojava virtuelnih likova u sasvim drugačijem svetlu prikazuje neka stalna pitanja na koja još nije dat, niti će izgleda ikada biti dat valjan odgovor: šta je stvarnost, šta je svet uopšte, šta je čovek (naročito telematski, virtuelni čovek, možda i tehnotronski čovek), kakvo je čovekovo mesto u stvarnosti i svetu, dokle svet i čovek, kao njegov deo, mogu da se razvijaju, da li virtuelna stvarnost ljudsku volju oslobađa ili zarobljava itd. Prihvatjiv odgovor na ta brojna pitanja koja su prvenstveno etička i biojuristička još nije pronađen. Očigledno, suština nije u konačnosti takvih odgovora, već u njihovoj trenutnoj korisnosti. Iza svake maske subjekta prava nalaze se stvarna ljudska lica.

Ključne reči: subjekt prava.- fizičko lice.- pravno lice.- virtuelni subjekt.- etika. 